\title{
HUBUNGAN POLA ASUH ORANG TUA DENGAN PERILAKU SOSIAL ANAK USIA PRASEKOLAH DI TK MENTARI SURABAYA
}

\author{
Ni Putu Widari ${ }^{1}$, Adellia Meidita Darmasari ${ }^{2}$ \\ ${ }^{1,2}$ STIKes William Booth Surabaya, Jalan Cimanuk No.20 Surabaya. \\ Email : putu.widari@yahoo.com
}

\begin{abstract}
ABSTRAK
Pola asuh dalam keluarga merupakan sebuah hal yang penting yang harus dilakukan oleh orang tua dalam menerapkan perilaku sosial yang baik pada anak, terutama pada anak usia prasekolah dimana usia prasekolah ini anak pertama kali untuk bersosialisasi di lingkungannya. Perilaku sosial yang juga dipengaruh oleh pola asuh orang tua selama dirumah. Dengan itu anak bisa berkembang dengan baik dalam usianya. Tujuan dari penelitian ini adalah mengiidentifikasi hubungan antara pola asuh orang tua dengan perilaku sosial anak usia prasekolah di TK Mentari Surabaya. Penelitian ini menggunakan desain penelitian korelasional. Jumlah populasi pada penelitian ini adalah sebanyak 17 orang siswa pada kelas TK A dan TK B dengan jumlah sampel yang digunakan sebagai responden penelitian adalah sebanyak 17 siswa. Pengambilan sampel dilakukan dengan cara Total Sampling. Instrumen penelitian yang digunakan adalah kuesioner mengenai pola asuh orang tua dan perilaku sosial. Setelah ditabulasi data yang ada dianalisis dengan menggunakan uji Spearman Rho Correlation dengan tingkat kemaknaan 0,05. Hasil penlitian ini menunjukan dari 17 responden didapatkan sebanyak 13 responden (76\%) mendapatkan pola asuh demokratis dan sebanyak 14 responden (82\%) memiliki perilaku sosial yang baik. Hasil uji statistik dengan Korelasi Spearman menunjukkan nilai signifikasi ( $p)$ sebesar $0,000(p<0,05)$ yang berarti terdapat hubungan antara pola asuh orang tua dengan perilaku sosial anak usia prasekolah. Melihat penelitian ini maka perlu adanya sebagai orang tua melakukan pendekatan melalui pola asuh yang tepat merupakan kunci agaterentuk perilaku sosialyangbaik terhadap anak. Oleh karena itu diharapkan orang tua dapat menerapkan pola asuh yang baik atau dengan memperkenalkan anak dilingkungan sekitar agar anak mampu bersosialisasi dengan baik dan sesuai dengan tahapan perkembangan umurnya.
\end{abstract}

Kata kunci: Pola asuh orang tua, Perilaku sosial, Anak prasekolah.

\begin{abstract}
The family is a more important things to be done by parents to apply good social behavior in children, especially on a preschool age where a preschool age children are the first in their neighborhood to be sociable. Social behavior by patterns dipengaruh also foster parents for home. With that children could well developed in age. The purpose of this research is mengiidentifikasi relations between the social behavior foster parents with children aged a preschool in kindergarten Mentari Surabaya. This study using. correlational study design The
\end{abstract}


size of the population in this study some 17 kindergarten students on class a and kindergarten $b$ sample survey respondents used as some 17. Students The sample done by means of total. Sampling Research instruments used is the pattern of foster parents and. social behavior After in tabular data analyzed using the spearman rho correlation with the 0,05. The results of this penlitian account for of 17 respondents obtained by 13 respondents ( $76 \%$ ) get the democratic foster and about 14 respondents ( $82 \%$ ) having social behavior good.Test statistics with the correlation spearman reflects the significance ( $p$ ) of 0,000 ( $p \&$ it; 0,05 ) which means there are the relationship between the adoptive parents with social conduct children preschool. See program needs to be the existence of this research as an old man making an approach by adopting proper foster is the key to good social behavior against children. Hence people expect them to foster parents could be applying a pattern which is good or by introducing children in their surroundings babies to socialize with residents with well as mandated by the stages in the development of the age.

The keyword: foster parents, social behavior, preschool children.

\section{PENDAHULUAN}

Keluarga sebagai kelompok masyarakat terkecil terbentuk oleh ikatan dua orang dewasa yang berlainan jenis kelamin, wanita dan pria serta anak-anak yang mereka lahirkan. Dalam kelompok ini arus kehidupan dikemudikan oleh orang tua. Orang tua memiliki tanggung jawab untuk mendidik, mengasuh dan membimbing anak-anaknya untuk mencapai tahapan tertentu yang menghantarkan anak untuk siap dalam kehidupan bermasyarakat (Hartanto, 2010). Orang tua dikatakan pendidik pertama karena dari merekalah anak mendapatkan pendidikan untuk pertama kalinya dan dikatakan pendidik utama karena pendidikan dari orang tua menjadi dasar bagi perkembangan dan kehidupan anak di kemudian hari. Pengaruh keluarga dalam pembentukan dan perkembangan kepribadian sangatlah besar artinya. Banyak faktor dalam keluarga yang ikut berpengaruh dalam proses perkembangan anak, seperti perkembangan sosial emosional anak yang dapat terbentuk dari lingkungan keluarga maupun dari lingkungan sekitar anak. Menurut Wibowo (2012) menguraikan bahwa keberhasilan keluarga dalam mendidik anaknya sangat tergantung pada model dan jenis pola asuh yang diterapkan para orang tua. Masa depan anak dikemudian hari akan sangat tergantung dari pengalaman yang didapatkan anak termasuk faktor pendidikan dan pola asuh orang tua. Masalah yang terjadi jika orang tua melalaikan tugas mereka untuk merawat, mengasuh dan mengajari anaknya tidak terjadi dengan maksimal maka akan berdampak pada perilaku sosial anak. Anak akan menjadi sering diam, dan tidak dapat atau susah berinteraksi dengan orang lain. Maka hal ini orang tua harus menerapkan pola asuh yang baik agar perilaku sosial anak menjadi lebih baik.

Anak prasekolah merupakan anak yang berusia 3-6 tahun dengan 
berbagai macam potensi yang dimiliki. Pada usia ini, perkembangan dipusatkan untuk menjadi manusia sosial dan belajar bergaul dengan orang lain. Potensi tersebut dirangsang dan dikembangkan guna membentuk pribadi anak yang tumbuh secara optimal (Supartini,2011). Sosialisasi pada anak prasekolah adalah proses mempelajari kebiasaan, cara hidup dan adat istiadat masyrakat tertentu. Kemampuan sosialisasi anak menjadi suatu aspek penting dalam perkembangan anak, karena masa anak di Taman Kanak-kanak (prasekolah) merupakan masa peralihan dari lingkungan masyarakat. Di dalam lingkungan sekolah anak tidak hanya memasuki dunia sosialisasi yang lebih luas melainkan anak juga menemukan suasana kehidupan yang berbeda, teman, guru, atau aturan-aturan yang berbeda dengan lingkungan keluarga. Sosialisasi pada anak prasekolah meliputi kemampuan anak menjalin hubungan dengan orang lain, kemampuan melakukan kegiatan bermain dan menggunakan waktu luang, kemampuan anak mengatasi situasi sosial yang dihadapi. Pertama berjuang untuk otonomi dan menggtrol diri mereka sendiri dan yang lain. Dan kemudian mengunakan bahasa, kognitif motor dan keterampilan sosial untuk mengumpulkan informasi tentang dunia (Soetjiningsih,2014).

Secara optimal sesuai umur anak (Depkes RI, 2011), Perkembangan sosial mengacu pada perkembangan anak dalam hubungannya dengan linkungan sosial agar mandiri dan dapat beritraksi untuk bersosialisasi. Para ahli pendidikan dan psikolog berpendapat bahwa kemandirian adalah menentukan keberhasilan dalam kehidupan seseorang (Retniwati,2010). Penelitian di Indonesia, dimana $(51,7 \%)$ pola asuh orang tua baik dan selebihnya $(41,7 \%)$ pola asuh orang tua tidak baik. Hal ini disebabkan oleh peran orang tua yang selalu memanjakan anak menyebabkan anak kurang matang secara sosial, kurang mandiri, kurang percaya diri. Prevalensi peduduk di Indonesia penduduk yang menerapkan pola asuh demokratis
$(53,85 \%)$, pola asuh otoriter $(23,66 \%)$ dan pola asuh permisif (22,49\%) (Fakhruddin,2015).

Berdasarkan wawancara peneliti dengan kepala sekolah TK Mentari Surabaya mendapatkan hasil bahwa jumlah anak yang bersekolah di TK Mentari Surabaya terdapat 42 siswa. Orang tua siswa pada TK Mentari Surabaya menerapkan beberapa pola asuh yang berbeda-beda. Dari data tersebut banyak anak yang bersekolah di TK Mentari Surabaya mengalami perilaku sosial yang berbeda-beda, ada yang hanya berdiam saja tidak mau bergaul dengan teman nyadengan jumlah 5 anak, ada yang mudah sekali bergaul dengan teman nya dengan jumlah 19 anak, ada yang yang mengalami terlalu sosial seperti terlalu aktif dan sangat bersosialisasi terhadap lingkungan nya dengan jumlah 18 anak.

Pola pengasuhan adalah asuhan yang di berikan ibu atau ayah atau pengasuh lain berupa sikap, dan perilaku dalam hal kedekatanya dengan anak, memberi makan, merawat, menjaga kebersihan, memberi kasih sayang, dan sebagainya (Septiani 2012). Menurut Teviana (2012) Pola asuh orang tua meliputi 3 hal antara lain. Pola asuh otoriter, autoriative, dan permisif. Pola asuh otoriter adalah gaya asuh yang menuntut anak, mengikuti perintah orang tua, tegas dan tidak memberi peluang anak untuk mengemukakan pendapat. Pola asuh authoritatif adalah gaya asuh yang memperlihatkan pengawasan ketat pada tingkah laku anak, tetapi juga responsive. Menghargai pemikiran, perasaan, dan mengikut sertakan anak dalam pengambilan keputusan. Pola asuh permisif adalah gaya asuh yang mendidik anak secara bebas, anak di anggap sebagai orang dewasa di beri kelongaran untuk melakukan hal yang di kehendakinya. Kepada anak, mau mengikuti permainan yang akan di lakukan sesuai dengan yang di jelaskan observasi sebelumnya askep tentang kemampuan sosialisasi anak yaitu tentang penerimaan sosial, kemampuan ini merupakan suatu keberhasilan anak untuk ikut berperan dalam kelompok sosialnya dan menunjukan 
rasa suka terhadap anggota kelompok lain, untuk bekerja sama dan bermain dengannya. Dampak dari pola asuh permisif membentuk anak seperti besifat implusif dan agresif, suka memberontak, kurang memiliki rasa percaya diri dan pengendalian diri, suka mendominasi, tidak jelas arah hidupnya, dan mengalami prestasi rendah. Menurut Dewi (2011), anak yang diasuh secara demokratis cenderung aktif, berinisiaatif, tidak takut gagal, karena anak di beri kesempatan untuk berdiskusi dalam pengambilan keputusan di keluarga. Orang tua memberi pengawasan terhadap anak dan kontrol yang kuat serta dorongan yang positif. Dampak dari pola asuh demokratis membentuk perilaku anak seperti memiliki rasa percaya diri, bersikap bersahabat, mampu mengendalikan diri (Self control), bersikap sopan, mau berkerja sama, memiliki rasa ingin tahu yang tinggi, mempunyai tujuan atau arah hidup yang jelas, berorientasi terhadap prestasi. Namun tidak menutupi kemungkinan akan berkembang pada sifat membangakan dan tidak mampu menyesuaikan diri. Menurut Adek (2010), pola asuh otoriter akan menghasilkan karakteristik anak yang penakut, pendiam, tertutup, tidak berinisiatif, gemar menentang, suka melanggar norma, berkepribadiaan lemah, cemas, dan menarik diri. Pola asuh ini akan menghasilkan anak dengan tingkah laku pasif dan cenderung menarik diri. Dampak dari pola asuh ini dapat membentuk anak seperti anak mudah tersinggung, penakut, pemurung, tidak merasa bahagia, mudah terpengaruh, mudah stress, tidak mempunyai arah masa depan yang jelas, dan tidak bersahabat. Sikap orang tua yang keras akan menghambat inisiatif.

Berdasarkan uraian latar belakang di atas di harapkan orang tua menjadi peran utama dalam mendidik anaknya, guru sebagai teman sebaya yang merupakan lingkungan ke dua anak karena orang tua yang berperan penuh dalam penentuan perkembangan dan melakukan pemantauan secara teratur dan berkesinabungan sedini mungkin pemantauan dapat di lakukan melalui kegiatan posyandu dan oleh guru di sekolah karena permasalahan perilaku anak tidak terlepas dari proses bersosialisasi anak. Peran guru dalam perilaku sosial anak prasekolah meliputi memberikan sebagai stimulasi pada anak, misalnya mengajak anak dalam permainan kelompok kecil. Maka dari itu peneliti tertarik melakukan penelitian di TK Mentari Surabaya dengan Judul Hubungan Pola Asuh Orang Tua Terhadap Perilaku Sosial pada Anak Usia Prasekolah.

\section{METODELOGI PENELITIAN}

Subyek dalam penelitian ini adalah orang tua dan siswa TK Mentari Surabaya, $\mathrm{N}=17$. Dalam penelitian ini peneliti menggunakan Rancangan penelitian korelasional, yaitu menjelaskan hubungan pola asuh orang tua siswa dengan perilaku social anak di TK Mentari Surabaya. Berdasarkan kriteria inkulsinya adalah orang tua yang bersedia untuk di teliti dan mau menandatangani informed consent. Pengumpulan data dengan Kuesioner pola asuh orang tua yang diberikan dengan menggunakan pertanyaan berisi tentang pola asuh demokratis, pola asuh otoriter, pola asuh permisif yang terdiri dari 24 pertanyaan masing-masing pola asuh ada 8 pertanyaan. Lembar observasi perilaku sosial anak prasekolah di TK Mentari Surabaya yang diisi oleh peneliti ada 9 pertanyaan dengan jawaban "ya" atau "tidak".

\section{HASIL}

Data khusus dalam bab ini menghubungkan mengenai pola asuh orang tua dan perilaku sosial anak prasekolah di TK Mentari Surabaya. Karakteristik dalam data khusus ini diantaranya adalah mengenai pola asuh orang tua dan perilaku sosial anak prasekolah di TK Mentari Surabaya.

Tabel 1. Karakteristik pola asuh orang tua responden di TK Mentari Surabaya pada tanggal 12 November 2019 


\begin{tabular}{cccc}
\hline No & $\begin{array}{c}\text { Pola Asuh Orang } \\
\text { Tua }\end{array}$ & $\begin{array}{c}\text { Jumlah } \\
\text { (f) }\end{array}$ & $\begin{array}{c}\text { Presentase } \\
(\%)\end{array}$ \\
\hline 1. & $\begin{array}{c}\text { Pola asuh } \\
\text { otoriter }\end{array}$ & 4 & $24 \%$ \\
\hline 2. & $\begin{array}{c}\text { Pola asuh } \\
\text { demokratis }\end{array}$ & 13 & $76 \%$ \\
\hline 3. & $\begin{array}{c}\text { Pola asuh } \\
\text { permisif } \\
\text { Total }\end{array}$ & 0 & $0 \%$ \\
\hline & 17 & $100 \%$ \\
\hline
\end{tabular}

Berdasarkan Tabel 1. dapat diketahui bahwa karakteristik responden dengan pola asuh orang tua yang demokratis merupakan responden terbanyak dengan jumlah 13 orang $(76 \%)$.

Tabel 2. Karakteristik perilaku sosial anak prasekolah di TK Mentari Surabaya pada tanggal 12 November 2019

\begin{tabular}{cccc}
\hline No. & Perilaku sosial & $\begin{array}{c}\text { Jumlah } \\
\text { (f) }\end{array}$ & $\begin{array}{c}\text { Presentase } \\
(\%)\end{array}$ \\
\hline 1. & Kurang & 0 & $0 \%$ \\
\hline 2. & Cukup & 3 & $18 \%$ \\
\hline 3. & Baik & 14 & $82 \%$ \\
\hline & Total & 17 & $100 \%$ \\
\hline
\end{tabular}

Berdasarkan Tabel 2. dapat diketahui bahwa perilaku sosial anak prasekolah dengan perilaku sosial yang baik merupakan responden terbanyak dengan jumlah 14 orang $(83 \%)$.

Tabel 3. Distribusi frekuensi responden pola asuh orang tua dengan perilaku sosial anak prasekolah di TK Mentari Surabaya bulan 12 November 2019

\begin{tabular}{ccccc}
\hline \multirow{2}{*}{$\begin{array}{c}\text { Perilaku } \\
\text { sosial }\end{array}$} & \multicolumn{3}{c}{ Pola Asuh Orang Tua } & Total \\
\cline { 2 - 4 } & $\begin{array}{c}\text { Otori } \\
\text { ter }\end{array}$ & $\begin{array}{c}\text { Demo } \\
\text { kratis }\end{array}$ & Permisif & \\
\hline Kurang & 0 & 0 & $0(0 \%)$ & $0(0 \%)$ \\
& $(0 \%)$ & $(0 \%)$ & & $3(18 \%)$ \\
\hline Cukup & 3 & 0 & $0(0 \%)$ & $14(82 \%)$ \\
& $(18 \%)$ & $(0 \%)$ & & $17(100 \%)$ \\
\hline Baik & 1 & 13 & $0(0 \%)$ & 14 \\
& $(6 \%)$ & $(76 \%)$ & & \\
\hline \multicolumn{4}{c}{ Total } \\
\hline
\end{tabular}

Uji statistik spearman 'Rho Correlation hasil sigifikansi $=0,000$

Berdasarkan Tabel 3. hasil tabulasi silang antara pola asuh orang tua dengan perilaku sosial anak prasekolah, didapatkan hasil persebaran data sebagai berikut. Perilaku sosial anak prasekolah kategori baik, jumlah anak yang mendapatkan pola asuh otoriter yaitu 1 anak (6\%), pada anak dengan pola asuh orang tua demokratis sebanyak 16 anak (94\%) dan tidak terdapat karakteristik pada anak dengan perilaku sosial baik pada pola asuh permisif. Perilaku sosial anak prasekolah kategori cukup, jumlah anak yang mendapatkan pola asuh otoriter yaitu 3 anak (18\%), dan tidak terdapat karakteristik pada anak dengan perilaku sosial cukup pada pola asuh demokratis dan permisif. Hasil uji statistik Spearman 'Rho Correlation dengan nilai sigifikansi 0,000. Dengan hasil p kurang dari 0,05 ini menandakan bahwa hipotesis H1 diterima, sehingga dapat disimpulkan bahwa terdapat hubungan antara pola asuh orang tua dengan perilaku sosial pada anak usia prasekolah di TK Mentari Surabaya.

\section{PEMBAHASAN}

Berdasarkan pembahasan mengenai pola asuh orang tua dan perilaku sosial anak usia prasekolah yang didapat dari responden di TK Mentari Surabaya pada subjek penelitian siswa kelas TK A dan TK B menunjukan hasil bahwa terdapat hubungan antara pola asuh orang tua yang demokratis terhadap perilaku sosial anak usia prasekolah. Hal ini dapat dilihat pada Tabel 3 mengenai distribusi frekuensi perilaku sosial dari ketiga pola asuh dimana perilaku sosial baik hanya terdapat pada responden dengan pola asuh demokratis yaitu sebanyak 13 anak (76\%). Dan dilanjutkan dengan perilaku sosial yang paling baik pada pola asuh demokratis yaitu sebanyak 13 anak (76\%). Hal ini juga dibuktikan oleh hasil uji statistik yang dilakukan dengan menggunakan analisa korelasi Spearman Rho yang menunjukan hasil signifikansi 0,000. Dengan hasil $p$ kurang dari 0,05 sehingga hipotesis H1 diterima dan menyatakan bahwa terdapat hubungan antara pola asuh orang tua terhadap perilaku sosial anak usia prasekolah di TK Mentari Surabaya. 
Menurut Solehuddin,2011 keluarga merupakan agen sosialisasi yang paling penting. Ketika anak-anak memasuki sekolah, guru mulai memasukkan pengaruh terhadap sosialisasi mereka seperti berbagi makanan jika salah satu temannya tidak membawa bekal, saling meminjam kan alat tulis jika salah satu temannya tidak mempunyai alt tulis tersebut contoh nya penghapus atau pensil, meskipun pengaruh teman sebaya biasanya lebih kuat dibandingkan dengan pengaruh guru dan orang tua. Studi tentang perbedaan antara pengaruh teman sebaya dan pengaruh orang tua terhadap keputusan anak pada berbagai tingkatan umur menemukan bahwa dengan meningkatnya umur anak, jika nasihat yang diberikan oleh keduanya (orang tua dan teman sebaya) berbeda maka anak cenderung lebih terpengaruh oleh teman sebaya. Hasil data penelitian hubungan pola asuh orang tua terhadap perilaku sosial anak usia prasekolah membuktikan bahwa kategori perilaku sosial yang baik hanya terdapat pada pola asuh demokratis. Orang tua yang menerapkan bimbingan dengan pendekatan yang demokratis pada anak pada usia prasekolah, cenderung menjadikan anak memiliki karakter perilaku sosial yang baik. Dalam hal ini dapat dilihat dari pola suh orang tua yang demokratis menjadikan anak dengan perilaku sosial yang baik seperti hal nya di sekolah dapat dilihat anak diajarkan bersosialisasi oleh gurunya. Contohnya jika salah satu teman dari anak tersebut sakit, mereka diajak untuk membantu teman nya untuk membezuk temen nya yang sakit. Jika salah satu teman nya tidak membawa bekal makanan, anak diajarkan untuk berbagi makanan dengan teman nya. Hal seperti ini yang perlu diajarkan disekolah maupun di keluarga agar anak dapat perkembang dengan baik.

Pada salah satu data yang ditemukan peneliti terdapat 4 anak (24\%) yang mendapatkan pola asuh otoriter, terdapat 1 anak $(6 \%)$ yang berperilaku sosial baik dan 3 anak (18\%) yang berperilaku cukup. Menurut teori Tridhonanto dan Agency
(2014) Pola asuh otoriter adalah pola asuh yang menggunakan pendekatan yang memaksakan kehendak, suatu peraturan yang dicanangkan orang tua dan harus dituruti oleh anak. Pendekatan seperti ini biasanya kurang responsif pada hak dan keinginan anak. Anak lebih dianggap sebagai objek yang harus patuh dan menjalankan aturan, dan ketidak berhasilan kemampuan dianggap ketidak mampuan. Hasil penelitian ini juga didukung oleh teori Wahyuning (2010), yang menyatakan bahwa pola asuh otoriter sangat kuat dalam mengontrol perilaku anak. Anak-anak diawasi dengan cukup ketat. Biasanya sikap orang responsif pada kebutuhan anak.Orang tua yang menggunakan pola asuh ini mempunyai kekuasaan penuh yang menuntut ketaatan mutlak, sehingga menghambat munculnya komunikasi terbuka antara orang tua dan anak. Komunikasi yang dilakukan lebih bersifat satu arah dan lebih sering berupa perintah, anak sebagai objek kurang mendengar dan cendrung diam dan menutup diri. Dari hasil tersebut dapat diketahui bahwa pola suh orang tua yang otoriter membuatanak tertekan dengan hasil anak cenderung diam, menutup diri mudah tersinggung, penakut. Akan tetapi pada hadil penelitian yang peneliti lakukan 1 anak (6\%) memiliki perilaku sosial yang baik dikarenakan anak mudah beradaptasi dengan lingkungan. Dalam hal ini lingkungan juga dapat mempengaruhi anak dalam perilaku sosial seperti misalnya disekolah anak bertemu dengan teman-temannya, dan bermain bersama dengan teman-temannya. Anak diajarkan untuk berkomunikasi yang baik dengan guru, teman dan orang tua nya.

\section{KESIMPULAN}

Kesimpulan yang didapat dari penelitian ini adalah sebagai berikut.

Terdapat hubungan antara pola asuh orang tua terhadap perilaku sosial anak usia prasekolah di TK Mentari Surabaya. 


\section{DAFTAR PUSTAKA}

Agency, Beranda dan Tridhonanto, Al.2014.Mengembangkan Pola Asuh Demokratis. Jakarta: Gramedia

Ahmad Mansur. 2011. Metode Penelitian dan Teknik Penulisan Laporan Karya Ilmiah. Bandung: PAAP FEB-UNPAD

Ali, 2010. Konsep dukungan keluarga. Jakarta: salemba medika

Azhari, Akyas. 2014. Psikologi Umum Dan Perkembangan. Jakarta: Teraju

Daeng Sari, Dini P. 2012. Metode Mengajar di Taman Kanak-Kanak. Depdikbud

Friedman, M. 2010. Buku Ajar Keperawatan keluarga : Riset, Teori, dan Praktek. Edisi ke-5. Jakarta: EGC

Harmoko. 2012. Asuhan Keperawatan Keluarga. Yogyakarta : Pustaka Pelajar

Hidayat, A.(2010). Pengantar Ilmu Keperawatan Anak, Jakarta: Salemba raya

Kozier. (2010). Buku Ajar Praktik Keperawatan Klinis. Edisi 5. Jakarta : EGC

L Johnson . (2010). Buku Ajar Keperwatan Keluarga. Yogyakarta : Nuha medika

Muhlisin, A. 2012. Keperawatan Keluarga. Yogyakarta: Gosyen Publishing

Mussen, P.H. 2010. Perkembangan dan Kepribadian Anak (Terjemahan Budiyanto, F.X., dkk). Jakarta : Archan.

Nursalam. (2011). Konsep dan penerapan metodologi penelitian ilmu keperawatan. Jakarta : Salemba Medika

Shochib, Moh, 2010. Pola Asuh Orang Tua Dalam Membantu Anak. Mengembangkan Displin Diri, Jakarta: PT Rineka Cipta
Solehudin. 2011. Konsep dasar Pendidikan Prasekolah.Bandung: Depdikbud. IKIP bandung.

Wahyuning, Wiwit dkk. 2010. Mengkomunikasikan Moral Kepada Anak. Jakarta: Gramedia. 